Chirurgia (2018) 113: 695-703

No. 5, September - October

Copyright $@$ Celsius

http://dx.doi.org/10.21614/chirurgia.113.5.695

\title{
Parietal Endometriosis: A Challenge for the General Surgeon
}

\author{
Nadejda Cojocari', Laura Ciutacu' ${ }^{2}$, Ioana Lupescu ${ }^{2,3}$, Vlad Herlea ${ }^{4,5}$, Mihaela Elena Vasilescu ${ }^{2,6}$, \\ Mirela Patricia Sîrbu Boeți ${ }^{1,2}$ \\ 'Department of General Surgery and Liver Transplantation, Fundeni Clinical Institute, Bucharest, Romania \\ 2"Carol Davila" University of Medicine and Pharmacy, Bucharest, Romania \\ ${ }^{3}$ Department of Radiology, Medical Imaging and Interventional Radiology, Fundeni Clinical Institute, Bucharest, Romania \\ ${ }^{4}$ Department of Pathology, Fundeni Clinical Institute, Bucharest, Romania \\ 5"Titu Maiorescu" University, Faculty of Medicine, Bucharest, Romania \\ ${ }^{6}$ Department of Gynecology, Life Memorial Hospital MedLife, Bucharest, Romania
}

Corresponding author:

Mirela Patricia Sirrbu Boeți, MD

Fundeni Clinical Institute

Fundeni Street, No. 258, Bucharest

district 2, Romania

E-mail: paboet@yahoo.com

\section{Rezumat \\ Endometrioza parietală: o provocare pentru chirurgul generalist}

Introducere: Endometrioza parietală (EP) este o patologie rară, care apare frecvent la femeile fertile, după intervenții chirurgicale sau ginecologice. Simptomatologia cvasipatognomonică constă în durere catamenială asociind sau nu formațiune palpabilă. Diagnosticul ridică probleme, deoarece adesea se poate confunda cu granulomul de fir, hematomul, hernia şi cancerul.

Pacienți şi metode: Între ianuarie 2007 şi decembrie 2017, 10 paciente cu EP au fost internate în clinica noastră pentru diagnostic şi tratament.

Rezultate: Vârsta medie a pacientelor a fost de 35,8 ani. Simptomul principal a fost durerea abdominală (9/10 paciente) şi examenul clinic a relevat prezența unei formațiuni palpabile la toate pacientele. Cinci paciente au fost diagnosticate preoperator cu EP, iar cinci incorect diagnosticate cu tumoră de perete abdominal (4 paciente) şi granulom de fir (1 pacientă). Opt paciente au avut istoric de intervenții ginecologice (operație cezariană, epiziotomie), iar 2 paciente nu au avut operatii în antecedente. Dimensiunile tumorilor au fost de 1-14 cm. Rezectia tumorală a necesitat reconstructia peretelui abdominal cu plasă de întărire sau substituție la 5 paciente, iar la restul plasa nu a fost necesară.

Concluzii: Studiul nostru confirmă că EP reprezintă o entitate chirurgicală rară şi sugerează necesitatea anamnezei şi examenului 
clinic minuțios, dar şi efectuarea examenelor imagistice, pentru elucidarea diagnosticului corect, în vederea stabilirii tratamentului chirurgical adecvat.

Cuvinte cheie: endometrioza parietală, endometrioza perineală, endometrioza abdominală, endometrioza cicatriceală, endometriom

\begin{abstract}
Background: Parietal endometriosis (PE) is a rare pathology, which usually develops in fertile women, after surgical or gynecological procedures. Its quasi-pathognomonic symptomatology consists in catamenial pain with or without palpable mass. The diagnosis can be challenging because it may be confused with stitch granuloma, hematoma, hernia or even cancer.

Patients and methods: Between January 2007 and December 2017, 10 female patients with PE were referred for diagnosis and surgery to our clinic.

Results: The mean age of the patients was 35.8 years. The primary symptom was pain (9/10 patients) and a palpable mass was present in all patients. Five cases were correctly preoperatively diagnosed as PE and five were misdiagnosed as tumors (4 patients) and stitch granuloma (1 patient). Eight patients had a history of gynecological procedure (cesarean section, episiotomy) and two had no previous surgical interventions. The size of the mass varied from $1 \mathrm{~cm}$ to $14 \mathrm{~cm}$. Resection of PE required parietal reconstruction with mesh in five patients but for the rest of the patients no mesh was needed.

Conclusions: Our study confirms PE as a rare surgical entity and indicates the necessity of thorough history and physical examination, as well as imaging exams, for making the correct diagnosis in order to choose the appropriate surgical procedure.
\end{abstract}

Key words: parietal endometriosis, perineal endometriosis, abdominal endometriosis, scar endometriosis, endometrioma

\section{Background}

Although Karl Freiherr von Rokitansky was believed to describe in 1860 the first case of endometrioma, referring to the disease as "sarcoma", the first unequivocal report of the presence of endometrial tissue within an ovary is contained in a paper published in 1899 by Russel, who incidentally found in the left ovary of a woman some 'areas, which were an exact prototype of the uterine glands and interglandular connective tissue' (cited by 1). Therefore, endometriosis is defined as the extrauterine spread of functional endometrial glands and stroma. It occurs in up to $15 \%$ of women of reproductive age (2). The most commonly affected organs are pouch of Douglas, ovaries and peritoneum covering the pelvic organs, followed by the bowel and urinary tract. Involvement of extrapelvic sites (e.g. central nervous system, lungs, pleura, kidney, lymph nodes, extremities, umbilicus, hernia sacs, bronchi, gallbladder, bladder, small intestine, large intestine, appendix, omentum, nasolacrimal canal) is unusual (3-7) as well as abdominal wall involvement. Abdominal wall endometriosis is defined as the presence of endometrial tissue superficial to peritoneum (8). Parietal endometriosis (PE) is a definition that includes not only the abdominal wall but also the perineal endometriosis. PE can be easily confused with an abscess, lipoma, hematoma, sebaceous cyst, stitch granuloma, incisional hernia or tumors (9), that can delay 
the surgical treatment or be followed by inappropriate surgical procedures, causing emotional and physical distress of the patient (10). The aim of this study is to report the experience of a Romanian general surgery center in diagnosing and treatment of this rare entity.

\section{Materials and Methods}

A retrospective, observational study with a case series of patients from the 130-bed Department of General Surgery and Liver Transplantation, Fundeni Clinical Hospital, was conducted from January 2007 to December 2017. Patients with histopathologically confirmed PE were identified from the surgical database of our institution. A total of 10 patients with PE were found in department's medical records. Data regarding age, signs and symptoms, present and past history of disorder, family pathology, imagistic findings, type of surgical intervention and postoperative course were analyzed.

\section{Results}

The highest addressability in our study was found to be in 2015 (3 cases) (Table 1). The study group is comprised of 10 women with mean age of 35.8 years (with range from 24 to 74 years). Five patients presented with abdominal mass in (Fig. 1) or above (Fig. 2) the

Table 1. Characteristics of the patients with PE

\begin{tabular}{|c|c|c|c|c|c|c|c|c|c|c|}
\hline No. & $\begin{array}{l}\text { Year of } \\
\text { address. }\end{array}$ & $\begin{array}{c}\text { Age } \\
\text { (years) }\end{array}$ & $\begin{array}{c}\text { Chief } \\
\text { complaint }\end{array}$ & $\begin{array}{l}\text { Surgical } \\
\text { history }\end{array}$ & $\begin{array}{c}\text { Initial } \\
\text { diagnosis }\end{array}$ & Localization & $\begin{array}{l}\text { Maximal } \\
\text { diameter }\end{array}$ & $\begin{array}{l}\text { Imaging } \\
\text { study }\end{array}$ & $\begin{array}{l}\text { Hospitalization } \\
\text { (days) }\end{array}$ & Surgery \\
\hline 1 & 2007 & 32 & cyclic pain & none & tumor & inguinal & $5 \mathrm{~cm}$ & US & 6 & EM \\
\hline 2 & 2007 & 32 & mass with d.v. & none & tumor & inguinal & $1.5 \mathrm{~cm}$ & US, IRM & 2 & $\mathrm{E}$ \\
\hline 3 & 2010 & 74 & pain & $\mathrm{c} / \mathrm{S}$ & tumor & hypogastrium & $4 \mathrm{~cm}$ & US & 5 & EM \\
\hline 4 & 2010 & 34 & cyclic pain & $\mathrm{C} / \mathrm{S}$ & PE & hypogastrium & $1 \mathrm{~cm}$ & US, IRM & 3 & $E$ \\
\hline 5 & 2011 & 32 & pain & $\mathrm{C} / \mathrm{S}$ & tumor & hypogastrium & $3 \mathrm{~cm}$ & US & 11 & EM \\
\hline 6 & 2016 & 42 & pain & $\begin{array}{c}2 \mathrm{C} / \mathrm{S} \\
\text { SG excision }\end{array}$ & SG & $\begin{array}{c}\text { hypogastrium }+ \\
\text { pelvic endometriosis }\end{array}$ & $2 \mathrm{~cm}$ & US,CT, IRM & 6 & $\mathrm{E}+\mathrm{THBA}$ \\
\hline 7 & 2013 & 28 & cyclic pain & $\begin{array}{c}2 \mathrm{C} / \mathrm{S} \\
\mathrm{PE} \text { excision }\end{array}$ & $\mathrm{PE}$ & hypogastrium & $14 \mathrm{~cm}$ & US, IRM & 7 & $E M+E M R$ \\
\hline 8 & 2015 & 24 & pain & episiotomy & PE & perineal & $4 \mathrm{~cm}$ & US & 4 & E \\
\hline 9 & 2015 & 28 & pain & episiotomy & $P E$ & perineal & $5 \mathrm{~cm}$ & US & 2 & $\mathrm{E}+\mathrm{SM}$ \\
\hline 10 & 2015 & 35 & cyclic pain & $\mathrm{C} / \mathrm{S}$ & PE & hypogastrium & $5 \mathrm{~cm}$ & US & 4 & EM \\
\hline
\end{tabular}

C/S: cesarean section, SG: stitch granuloma, PE: parietal endometriosis, US: ultrasound, d.v.: dimensional variations, E: simple excision,

EM: excision with mesh repair, M: myometrectomy, THBA: total hysterectomy with bilateral adnexectomy, SM: sphincter ani myorrhaphy

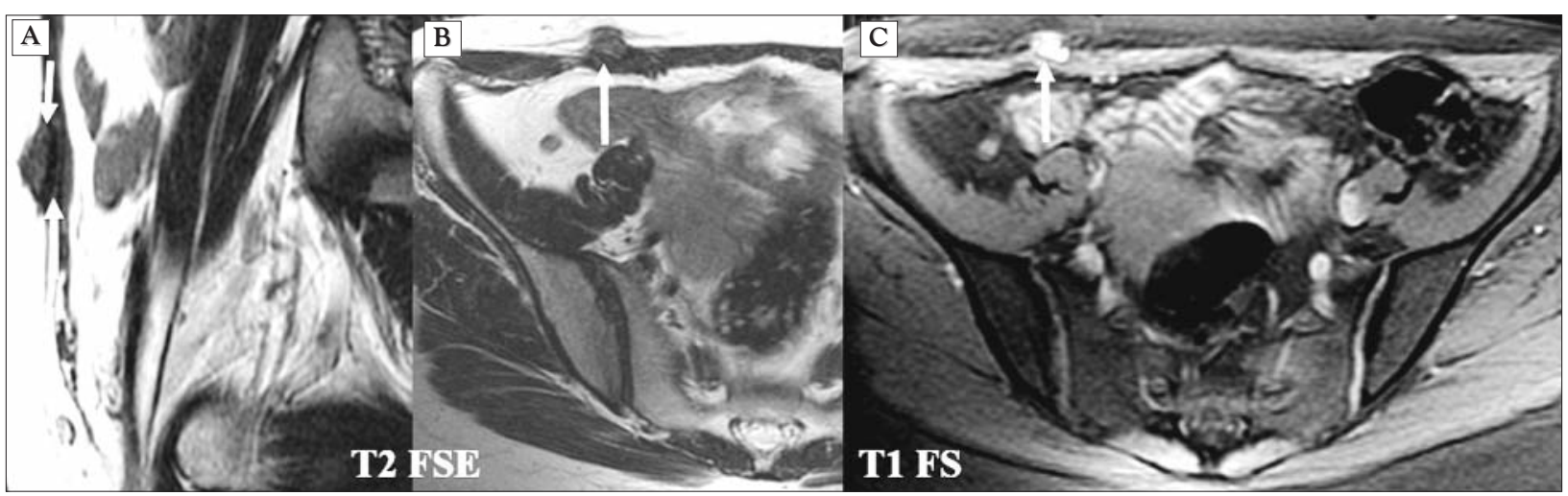

Figure 1. Small foci of abdominal wall endometriosis (arrow): after cesarean delivery scars - MRI evaluation in sagittal T1 FSE (A), axial T2 FSE (B) and T1 EG Fat Sat (C) plane 


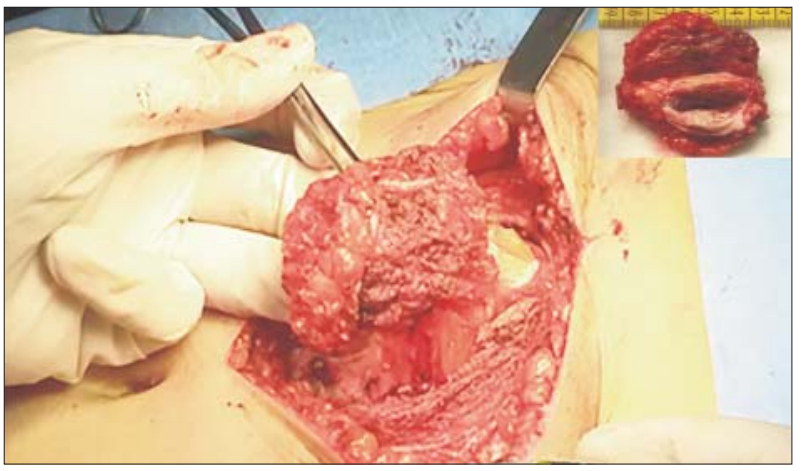

Figure 2. Involvement of rectus abdominal muscles in PE located above the Phannenstiel scar on the median line. In the right upper box: macroscopic honey-comb appearance of the resected specimen

surgical scar after cesarean section; in one case the mass appeared after hysterectomy; in two cases the mass was described at episiotomy site (Fig. 3); in the remaining two cases, inguinal localization was identified, in the absence of any surgical scar.

In the analyzed lot, two patients had PE associated with pelvic endometriotric lesions involving the uterus and ovaries (Fig. 4). The main presenting complaint for 9 of 10 patients was pain, with cyclic manifestation in four of them. All the patients presented palpable mass with tumor dimensions ranging from 1 to $14 \mathrm{~cm}$ (mean diameter $4.45 \mathrm{~cm}$ ). The patient without any pain complaint had cyclic size variations of the palpable mass. One patient

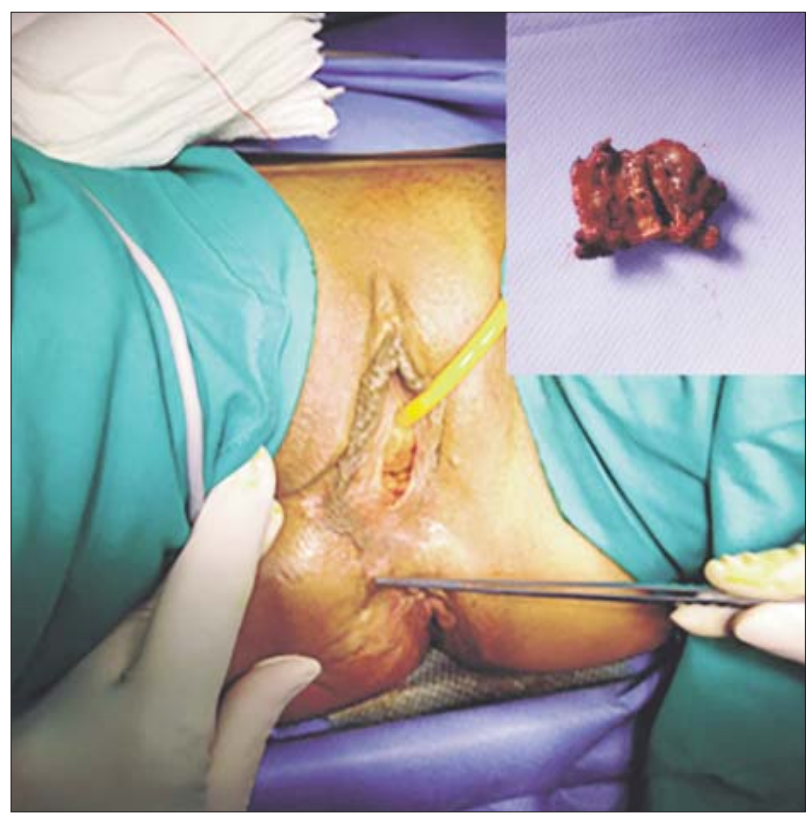

Figure 3. PE at episiotomy site. In the right upper box: macroscopic honey-comb appearance of the resected specimen

accused associated dyspareunia and dysuria. Two patients had recurrence after anterior surgical interventions for PE. In two patients comorbidities were found: non-Hodgkin lymphoma ( 1 patient), von Willebrand disease (1 patient). All the patients were investigated by bidimensional and color Doppler ultrasound. In four cases, the diagnosis was sustained by magnetic resonance imaging (Fig. 5). It was
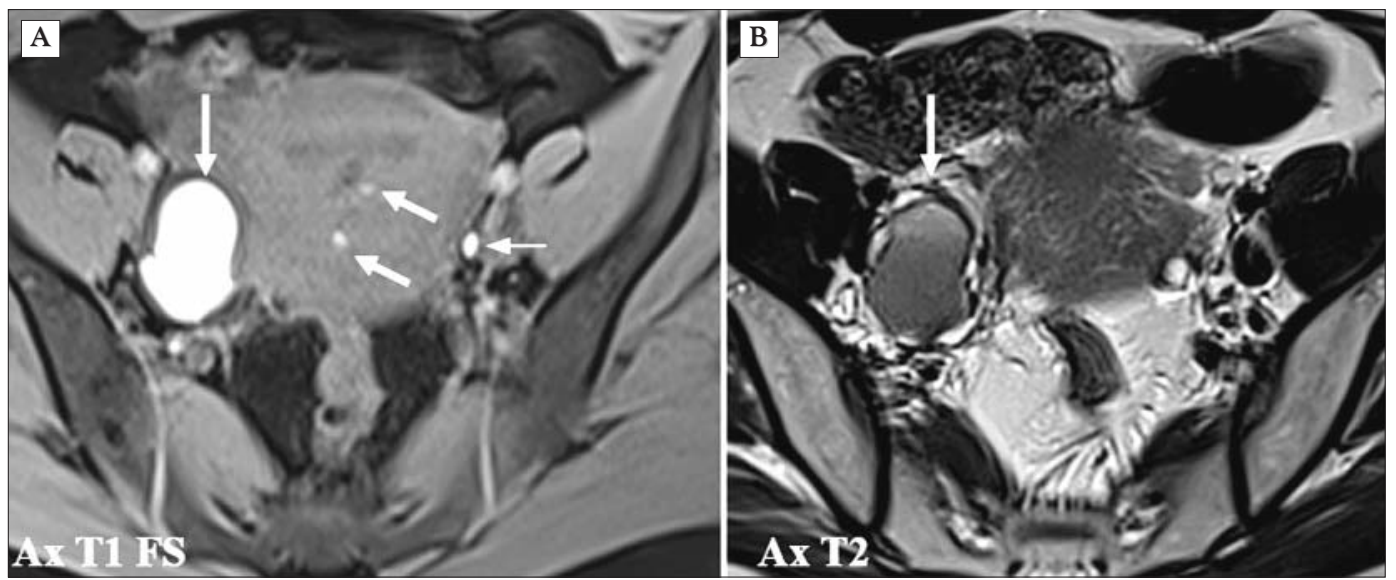

Figure 4. Endometriosis with different locations. Right ovarian cystic lesion (arrows) hyperintense on fatsuppressed T1-wi (a) and hypointense on T2-wi (b) - typical MRI findings for endometrioma; note also a very small hyperintense foci into the left ovary (arrow) and few small hyperintense spots on fat-suppressed T1 EG within the myometrium (arrows) 


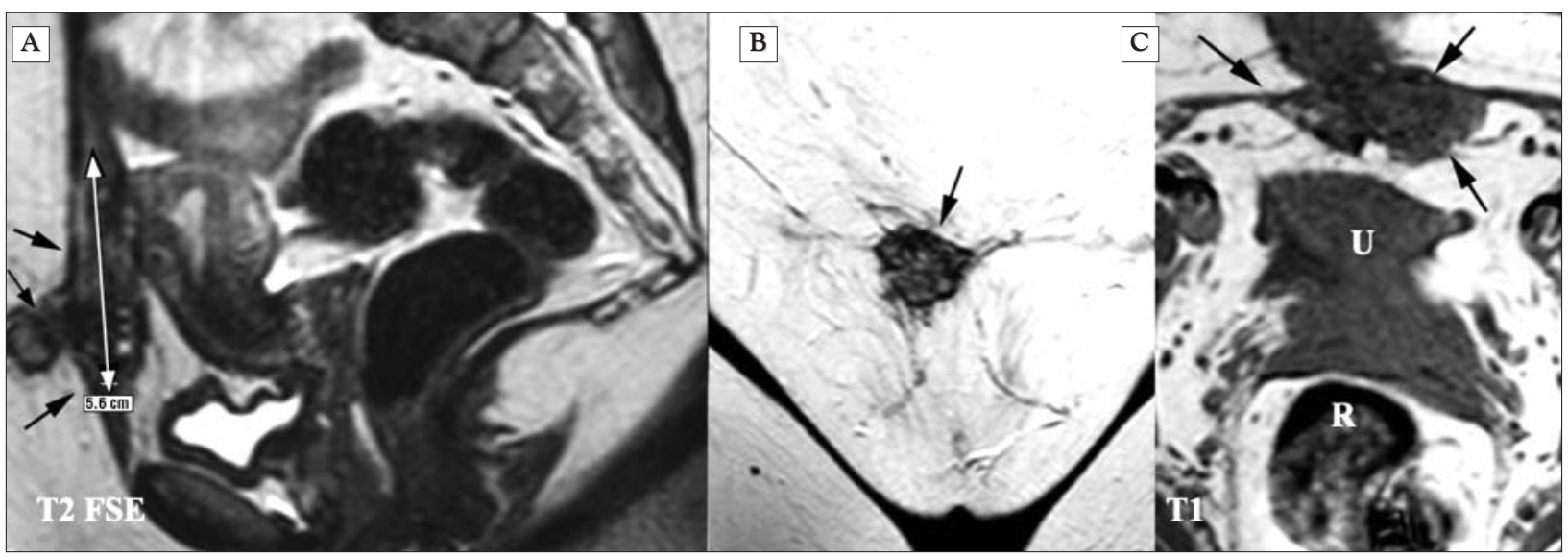

Figure 5. Abdominal wall endometriosis - MRI evaluation in sagital (A), coronal (B) T2-wi and axial T1wi plane shows into the anterior abdominal wall, at the level of the surgical scar, an infiltrating heterogeneous iso-/ high-signal-intensity mass involving both muscular abdominal wall, subcutaneous fat (arrows) and uterus

performed with moderate repletion of the urinary bladder and using an intravenously administered antispasmodic agent (Buscopan). Images were acquired on a 1.5-T MRI system. Our MRI protocol included axial fatsuppressed T1 EG-weighted images (wi) in axial plane, and axial, oblique coronal, and sagittal T2-weighted sequences. Fat-suppressed T1-weighted sequences are the most sensitive for the detection of bloody foci (Fig. 1 and Fig. 4), whereas high-resolution T2-weighted images are used for the evaluation of fibrotic lesions, notably those that involve the pelvic ligaments, retrocervical space, or prevesical recess. Only in one patient ultrasound, computed tomography and magnetic resonance imaging were performed all together.

Laboratory test abnormalities were found only in 2 patients that had CK-MB values elevated and respectively serum fibrinogen increased. The levels of serum tumoral markers were not checked. In half of the patients PE was diagnosed preoperatively, while four patients had preoperative diagnosis of abdominal wall tumor and one - stitch granuloma. All our patients were submitted to surgical excision of endometrioma. Three frozen section examinations were carried out during operation; two gave the diagnosis of $\mathrm{PE}$, one - inflammatory tumor. In 3 cases, besides the $\mathrm{PE}$ resection with wide margins, other procedures were associated to remove the involved tissues: endomyometrial resection (EMR) with hysterorrhaphy (1 patient), myorrhaphy of anal sphincter (1 patient), total hysterectomy with bilateral adnexectomy (1 patient). Four of six patients with hypogastric PE needed mesh repair of the abdominal wall. One of two patients with $\mathrm{PE}$ in the right groin required prosthetic material interposition. Both patients with perineal endometriosis had no need of mesh placement.

The final diagnosis of $\mathrm{PE}$ in all patients was made by histopathologic examination on paraffin of the surgical specimen. The margins of the specimens were confirmed to be free of disease (Fig. 6A). Histological examination reported the lesion involving muscle tissue (5 cases), round ligament (2 cases), subcutaneous tissue (2 cases) and one specimen associated anterior uterine wall invasion. In one patient immunohistochemistry tests were performed, showing ER-nuclear index $100 \%$ positive, PGR nuclear index 100\% positive, WT1 absent in glandular epithelium, focally positive in stromal cells, CA 125 diffusely positive in glandular epithelium, Ki67 nuclear index $1-2 \%$ positive in glandular epithelial cells (Fig. 6B-F). The mean hospital stay was 5.2 days (4-11 days). Up to now no recurrence of $\mathrm{PE}$ was encountered in our patients during close postoperative follow-up. 


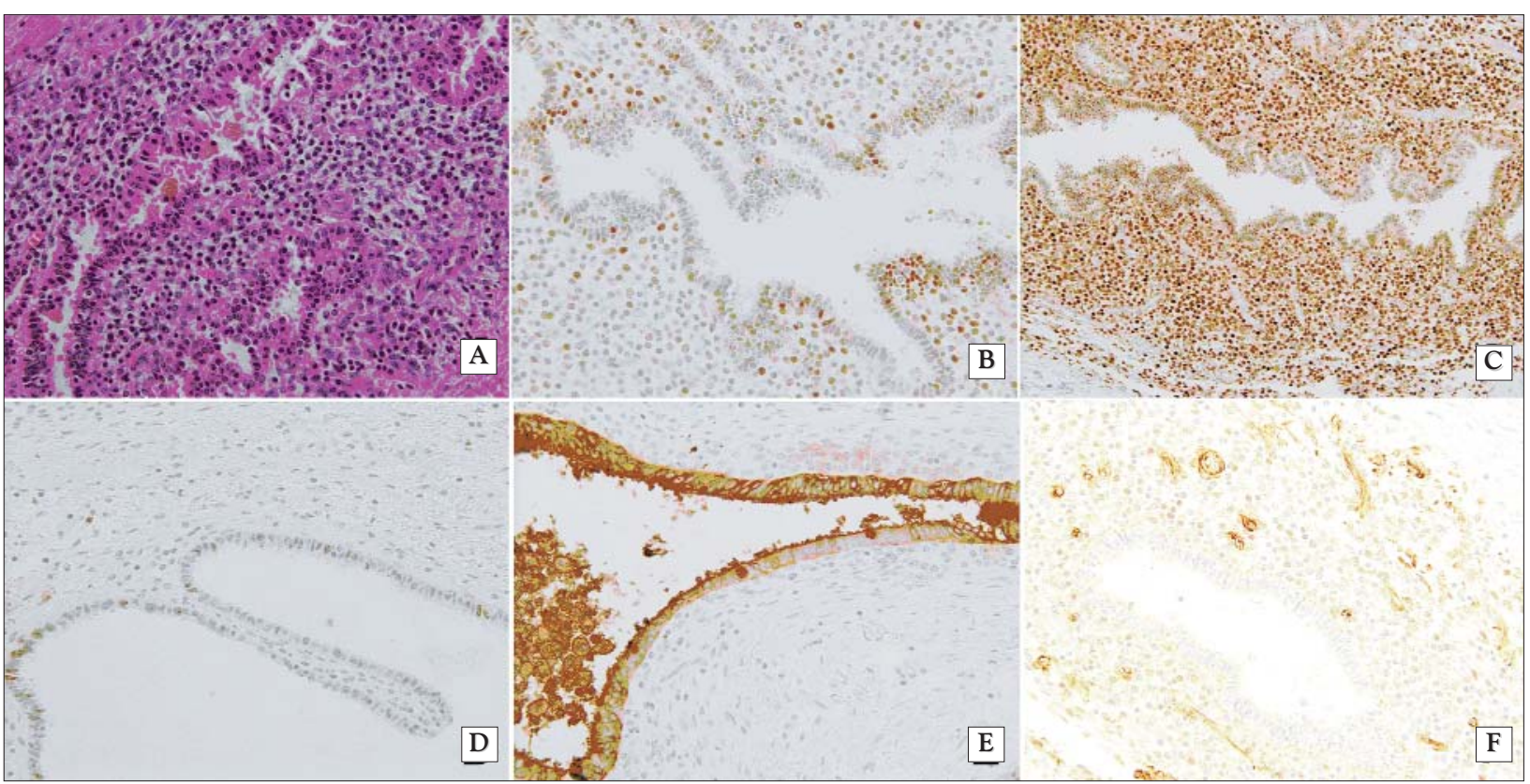

Figure 6. (A) Endometriotic glands with stromal cells, hematoxylin \& eosin stain (400X); (B) ER positive nuclear staining by immunohistochemistry (400X); (C) PR positive nuclear staining by immunohistochemistry (400X);

(D) Immunohistochemistry with Ki-67 positive nuclear staining in rare cells (400X); (E) Immunohistochemistry with CA-125 positive nuclear staining in epithelium of endometriotic glands (400X); (F) Immunohistochemistry with WT1 positive nuclear staining in associated stromal cells (400X)

\section{Discussions}

The rarity of $\mathrm{PE}$ is attested in the literature with paucity of reported cases. However the biggest recently reported study included 227 patients treated in a gynecological department (11). General surgeons are seldom involved in treating $\mathrm{PE}$, the biggest series treated in a surgical department being of only 15 cases (12). PE incidence reaches $1.08-2 \%$ after hysterotomy (13), $0.03-1 \%$ after cesarean section (14), 0.06-0.7\% after episiotomy (15), values that are significantly lower than those reported in the past (16-18). This reduction in incidence is partially due to the preventive methods that gained popularity after Wasfie had suggested cleaning thoroughly and washing the incision area with saline after surgeries on uterus and uterine tubes (19). However, PE does not necessarily occur after gynecological procedures, instances of $\mathrm{PE}$ being observed after laparoscopic procedures, appendectomy, inguinal hernia repair, colorectal surgery (20-23) or even de novo (24). We encountered two patients with groin masses with no previous surgical scar. PE may coexist with pelvic endometriosis in $26 \%$ of patients (3). Two of the patients in our series had associated ovarian and uterine endometriosis.

Pathogenesis of PE can be explained with several theories (25): direct inoculation during surgical interventions and subsequent stimulation by estrogens, that could be the incriminating factor in eight of our patients with previous gynecological interventions; retrograde menstruation theory (26); immune system dysfunction and autoantibody formation (similar to autoimmune diseases); coelomic metaplasia theory; lymphatic and blood dissemination of endometrial cells, that could explain the groin PE in two of our patients; stem cell theory; embryonic rest theory that explains the endometriosis presence in men $(27,28)$. Alcohol consumption and heavy menstrual flow may act as predisposing factors to disease occurrence. Instead, high parity is considered to be a protective factor against $\mathrm{PE}$ (29). Clinically, PE usually respects the triad 
described by Esquivel: palpable mass, catamenial pain and history of cesarean section (30). Cyclicity of pain is not found in all cases. Other symptoms such as increasing size of lump, bleeding, discharge, skin discoloration, dysmenorrhea, infertility and dyspareunia are mentioned (4). In our study, catamenial pain was rated as only $40 \%$, which could explain the rate of 50\% misdiagnoses before operation. The accuracy of preoperative diagnosis is reported between $20 \%$ and 50\% (31). One patient had the mass and cyclical pain located away from the Pfannenstiel incision, supposedly because of the vertical incision of the peritoneum. Time interval elapsed from last operation and presentation could range from 6 months to 10 years (9). Our study confirmed the literature results, with a preoperative diagnosis of $\mathrm{PE}$ in half of the cases. This denotes that thorough supplementary investigations should be performed. Abdominal sonography is the most cost-efficient investigation. It may reveal hypoechoic inhomogenous echo-texture with scattered hyperechoic echoes and irregular margins, often spiculated, surrounded by a hyperechoic ring of variable width and continuity. On color Doppler examination, single pedicles may be identified at periphery of the mass (32). If the lesion is sizable or expending beyond abdominal wall, then the patients should undergo MRI, in order to better characterize the mass anatomy and its surrounding structures (33). The major role of MRI is to depict the extent of the disease preoperatively. MR characteristics of PE may be nonspecific, showing a solid enhancing mass in the abdominal wall (34). In cases in which MRI shows a hyperintense heterogenous lesion associated with anterior abdominal or pelvic wall surgical scarring on both T1- and T2-weighted images, subacute hemorrhage within endometrioma may be the reason (35). Imagistic results may be helpful in surgical planning to estimate the parietal defect and need of mesh parietal repair (8). In our study, MRI was useful for evaluating the depth of infiltration in $40 \%$ of patients. Although fine-needle aspiration cytodiagnosis was used by other authors and gave a precise diagnosis, its application remains controversial because of risk of endometrioid tissue dissemination (36). The serum level of CA-125 was reported in the literature to be normal or slightly increased (20). Because PE is easily confound with surgical lesions like umbilical and inguinal hernias, abscess, stitch granuloma, hematoma, tumors, because imagistic methods are nonspecific, and, moreover, some patients have no antecedents of operations, histopathological analysis of the surgical specimen is mandatory (24). The histopathological diagnosis was performed in all our patients and was based on recognition of at least 2 from 3 criteria: endo-metrial stroma, endometrial glands and hemosiderin pigment (37). Medical treatment with combined oral contraceptives, progestogens (dienogest), anti-estrogens (danazol), gonadotropin-releasing hormone agonists (triptoreline, gosereline) or aromatase inhibitors (letrozol) provides temporary alleviation of symptoms with their recurrence after drug cessation (11) and could be recommended to prevent recurrences after PE resection. Surgical excision of $\mathrm{PE}$ is unanimously considered to be the only curative treatment. However, less invasive, in situ destructive methods like cryoablation (38), high intensity focus ultrasound (39) or ethanol injection (40) have been reported, but more time should pass to decide upon their safety and efficacy. It is preferred to conduct the operation under general anesthesia. Wide surgical excision with at least $1 \mathrm{~cm}$ margin resection is advisable. Sometimes preoperative placement of a hook wire under ultrasound guidance is useful in tracking small, impalpable lesions (41). If the lesion is large and extends to deeper tissues such as muscle, aponeurosis or peritoneum and even invades other organs, visceral resections and reconstructive techniques may be required (42). In our series, $50 \%$ of the patients had invasion of muscular tissue, 20\% - round ligament and $10 \%$ - uterus. Mesh repair of the anterior abdominal wall was necessary in $50 \%$ of patients. Another useful surgical technique for anterior wall reconstruction is rotation of aponeurotic muscle flap (43). The involvement of the anal sphincter is a rare occurrence in perineal endometriosis. The clinical bimanual 
simultaneous examination of vagina and rectum is important to appreciate the local extension of the mass. In case of sphincter involvement, anal manometry and endoanal ultrasound are recommended. The surgical procedure implies removal of the lesion with part of the external anal sphincter followed by its reconstruction (e.g. "overlapping" fashion, "apposition" technique) (44). For one of our patients with endometriosis at the level of episiotomy scar, a careful dissection of the nodule was done in order to preserve as much as possible from the external anal sphincter while removing all the lesion with free margin of at least $0,5 \mathrm{~cm}$; the excision was followed by myorraphy of levator ani to secure the perineal body. Recurrence after surgical excision is rare in $\mathrm{PE}$, if properly diagnosed and treated, as well as its malignant transformation (45).

\section{Conclusions}

Even if rarely encountered by the general surgeon, PE must be thought in all female patients with/without previous surgical or obstetrical interventions, that complain of catamenial pain at the level of abdominal wall or perineum. The diagnosis should be sustained by imagistic studies and confirmed by histopathology. The only curative treatment remains large excision of $\mathrm{PE}$ with disease-free margins under general anesthesia. Mesh repair of abdominal wall and partial resection with/ without reconstruction of anal sphincter are sometimes required and fall into the competence of general surgery. Insufficient awareness of general surgeons about PE may lead to misdiagnosis and improper treatment, that may result in prolonged suffering of the patient.

\section{Conflict of Interest}

All author declare that they have no conflict of interest.

\section{References}

1. Benagiano G, Brosens I, Donatella L. The history of endometriosis. Gynecol Obstet Invest. 2014;78(1):1-9.

2. Ranney B. Endometriosis. Gynecol Obstet Invest. 2014;78(1):1-9.
3. Blanco RG, Parithivel VS, Shah AK, Gumbs MA, Schein M, Gerst PH. Abdominal wall endometriomas. Am J Surg. 2003;185:596-8.

4. Patterson GK, Winburn GB. Abdominal wall endometriomas: report of eight cases. Am Surg. 1999:65:36-9.

5. Olive SL, Schwartz LB. Endometriosis. N Engl J Med. 1993; 328:1759-69.

6. Rawson JM. Prevalance of endometriosis in asymptomatic women. J Reprod Med. 1991;36:513-5.

7. Wolf G, Singh K. Cesarean scar endometriosis: A review. Obstet Gynecol Surv. 1989;44:89-95.

8. Horton JD, Kent JD, Ahnfeldt EP, Wagner M. Abdominal wall endometriosis: a surgeon's perspective and review of 445 cases. Am J Surg. 2008;196:207-12.

9. Koger KE, Shatney CH, Hodge K, McClenathan JH. Surgical scar endometrioma. Surg Gynecol Obstet. 1993:177:243e6.

10. Danielpour PJ, Layke JC, Durie N, Glickman LT. Scar endometriosis - a rare cause for a painful scar: A case report and review of the literature. Can J Plast Surg. 2010;18:19-20.

11. Ding CD, Hsu S. Scar endometriosis at the site of cesarean section. Taiwanese J Obstet Gynecol. 2006;3:247-9.

12. Picod G, Boulanger L, Bounoua F, Leduc F, Duval G. Abdominal wall endometriosis after cesarean section: report of fifteen cases. Gynecologie Obstetrique \& Fertilité. 2006; 34:8-13.

13. Ara S, Fatima A, Aleem M. Scar endometriosis - A rare disease occurrence. A.P.M.C. 2009;3(2):162-5.

14. Goel P, Devi L, Tandon R, Saha PK, Dalal A. Scar endometriosis - A series of six patients. Int J Surg. 2011;9:39-40.

15. Nominato NS, Prates LFVS, Lauar I, Morais J, Maia L, Geber S. Endometriose de cicatriz cirúrgica: estudo retrospective de 72 casos (Scar endometriosis: a retrospective study of 72 patients). Rev Bras Ginecol Obstet. 2007;29(8):423-7.

16. Gottleib T. Endometriosis in the vaginal scar following hysterotomy for therapeutic abortion; report on 100 cases. Acta obstet. gynec. Scand. 1957;36:194.

17. Dutta DK, Dutta B, Scar endometriosis - a clinicopathological study. J Obst Gyn India. 1992; 42:831-4.

18. Pal A, Sarkar P, DuttaGupta H. Scar endometriosis. J Obstet Gynecol India. 1991;41:537-40.

19. Wasfie T, Gomez E, Seon S, Zado B. Abdominal wall endometrioma after cesarean section: A preventable complication. Int Surg. 2002;87:175-7.

20. Cozzolino M, Magnolfi S, Corioni S, Moncini D, Mattei A. Abdominal wall endometriosis on the right port site after laparoscopy: case report and literature review. The Oschsner J. 2015:15:251-55.

21. Mizutani K, Nakanashi K, Hiraki M, Ono H, Ozaki K, Nagano T. A case of abdominall wall endometriosis after appendectomy. $\mathrm{J}$ of Japan Surg Association. 2012;73(4):993-996.

22. Cinardi N, Franco S, Centonze D, Giannone G. Perineal scar endometriosis ten years after Miles' procedure for rectal cancer: Case report and review of the literature. Int J Surg Case Rep. 2011;2(6):150-53.

23. Ducarme G, Uzan M, Poncelet C. Endometriosis mimicking hernia recurrence. Hernia. 2007;11(2):175-77.

24. Wong WS, Lim CE, Luo X. Inguinal endometriosis: an uncommon differential diagnosis as an inguinal tumour. ISRN Obstet Gynecol. 2010;2011:272159

25. Ahn SH, Monsanto SP, Miller C, Singh SS, Thomas R, Tayade C. Pathophysiology and Immune Dysfunction in Endometriosis. Biomed Res Int. 2015;2015:795976.

26. Ridley JH, Edwards JK. Experimental endometriosis in the human. Am J Obstet Gynecol. 1958;76(4):783-9.

27. Jabr FI, Mani V. An unusual cause of abdominal pain in a male patient: Endometriosis. Avicenna J Med. 2014;4(4):99-101.

28. Simsek G, Bulus H, Tas A, Koklu S, Yilmaz SB, Coskun A. An unusual cause of inguinal hernia in a male patient: endometriosis. Gut Liver. 2012;6(2):284-85. 
29. de Oliveria MA, de Leon AC, Freire EC, de Oliveria HC, Study SO. Risk factors for abdominal scar endometriosis after obstetric hysterotomies: a case-control study. Acta Obstet Gynecol Scand. 2007:86:73-80.

30. Esquiel-Estrada V, Briones-Garduno JC, Mondragon-Ballesteros R. Endometriosis implant in cesarean section surgical scar, Cir Cir. 2004;72(2):113-5.

31. Bektas H, Bilsel Y, Sari YS, Ersoz F, Koc 0, Deniz M et al. Abdominal wall endometrioma; a 10 year experience and brief review of the literature. J Surg Res. 2010;164(1):e77-81.

32. Francica G. Reliable clinical and sonographic findings in the diagnosis of abdominal wall endometriosis near cesarean section scar. World J Radiol. 2012;4(4):135-40.

33. Solak A, Genc B, Yalaz S, Sahin N, Sezer TO, Solak I. Abdominal wall endometrioma: ultrasonographic features and correlation with clinical findings. Balkan Med J. 2013;30(2):155-60.

34. Hensen J-H, Van Breda Vriesman A.C, Puylaert J.B.C. M. Abdominal Wall Endometriosis: Clinical Presentation and Imaging Features with Emphasis on Sonography. AJR. 2006;186:616-620.

35. Gidwaney R, Badler RL, Yam BL, Hines JJ, Aleseeva V, Donovan V et al. Endometriosis of abdominal and pelvic wall scars: multimodality imaging findings, pathologic correlation, and radiologic mimics. Radiographics. 2012;32(7):2031-43.

36. Gupta RK. Fine-needle aspiration cytodiagnosis of endometriosis in cesarean section scar and rectus sheath mass lesions - a study of seven cases. Diagn Cytopathol. 2008;36(4):224-6.

37. Khamechian T, Alizargar J, Mazoochi T. 5-year data analysis of patients following abdominal wall endometrioma surgery. BMC
Womens Health. 2014;14:151-6.

38. Maillot J, Brun JL. Dubuisson V, Bazot M, Grenier N, Cornelis FH. Mid-term outcomes after percutaneous cryoablation of symptomatic abdominal wall endometriosis: comparison with surgery alone in a single institution. Eur Radiol 2017; 27(10):4298-306.

39. Zhu X, Chen L, Deng X, Xiao S, Ye M, Xue M. A comparison between high-intensity focuse ultrasound and surgical treatment for the management of abdominal wall endometriosis. BJOG. 2017;124(3):53-8.

40. Bozkurt M, Cil AS, Bozkurt DK. Intramuscular abdominal wall endometriosis treated by ultrasound-guided ethanol injection. Clin Med Res. 2014;12(3-4):160-5.

41. Hull ML, Gun MT, Ritossa M. Hook-wire insertion facilitates the excision of scar endometriosis. BJOG. 2006;113(6):744-6.

42. Ecker AM, Donnellan NM, Shepherd JP, Lee TT. Abdominal wall endometriosis: 12 years of experience at a large academic institution. Am J Obstet Gynecol. 2014;211(4):363.e1-e5.

43. Leite GK, Carvalho LF, Korkes H, Guazzelli TF, Kenj G, Viana AT. Scar endometrioma following obstetric surgical incisions: retrospective study on 33 cases and review of the literature. Sao Paulo Med J. 2009:127(5):270-7.

44. Barisic GI, Krivokapic ZV, Jovanovic DR. Perineal endometriosis in episiotomy scar with anal sphincter involvement: report of two cases and review of the literature. Int Urogynecol J Pelvic Floor Dysfunct. 2006;17(6):646-9.

45. Ijichi S, Mori T, Suganuma I, Yamamoto T, Matsushima H, Ito F et al. Clear cell carcinoma arising from Cesarean Section scar endometriosis: case report and review of the literature. Case Rep Obstet Gynecol. 2014;2014:642483. 